\title{
Correlation Of Knowledges and Attitudes Among Female Senior High School Students in Badung Toward Cervical Cancer and Their Participation in Human Papilloma Virus Vaccinations
}

\author{
Putu Indah Budi Apsari ${ }^{1 *}$, I Nengah Kapti ${ }^{1}$, Putu Risma Yuvita Riadi ${ }^{1}$ \\ ${ }^{1}$ Faculty of Medicine and Health Sciences, Universitas Warmadewa University \\ *putuindah51@yahoo.com
}

\begin{abstract}
The prevalence of cervical cancer in Bali in 2015 was $0.7 \%$ with an estimated number of 1,438 people. Government of Badung supports the program by subsidizing HPV vaccination to female high school students, but there were still many students who not participated because of many factors, i.e. knowledges and attitudes toward cervical cancer. The purposed of this studies were to determine the correlation between knowledges with the attitudes of female high school students in Badung toward cervical cancer and HPV vaccination participations. This cross-sectional analytic study used 100 female students in SMAN 1 Kuta, SMK Pariwisata Triatma Jaya and SMAN 1 Kuta Utara as samples. Data were collected by personal interviewed using prepared questionnaires and analyzed using Somers'd correlation test. Results showed there was significant correlation between knowledges and attitudes $(\mathrm{p}=0.036, \mathrm{r}=0.214)$, and no significant correlation between attitudes and HPV vaccination participations $(\mathrm{p}=0.207)$. For the government of Badung, it is hope to continue free HPV vaccination program and for the local health centre to hold counseling about HPV for female senior high school students routinely.

Keyword : Knowledges, Attitudes, Virus Vaccinations
\end{abstract}

\section{Introduction}

Cervical cancer is the primary cancer of the cervix originating from epithelial metaplasia in the transitional area between the vaginal mucosa and the cervical canal. The primary cause is Human Papilloma Virus (HPV) infection. [1] Based on data from the International Agency for Research on Cancer (IARC) in 2015, cervical cancer ranks third in the world's deadliest in women. The incidence of cervical cancer in Indonesia is 16 per 100,000 population.[2] The prevalence of cervical cancer in Bali in 2015 was $0.7 \%$ with an estimated number of 1,438 people Badung Regency was the first to carry out primary prevention through HPV vaccination in high school (SMA) considering the onset of cervical cancer infection can occur at the age of teens and the effectiveness of vaccines is very good in adolescents.[3] HPV, one of them is their knowledge and attitude about cervical cancer. This study aims to assess the relationship between knowledge and attitudes regarding cervical cancer in high school / vocational school students in Badung Regency and their participation in HPV vaccination. 


\section{Method}

\subsection{Data Collection}

The study was conducted in three high schools / vocational schools in Badung Regency which were selected using cluster sampling techniques, namely, Public High School Kuta, Triatma Jaya Tourism Vocational School, and North Kuta 1 Public High School in December 2017. This type of research is analytical research with cross-sectional design. The population in this study was female students Kuta Public High School, Triatma Jaya Tourism Vocational School, North Kuta Public High School 2017/2018 academic year. Samples that met the inclusion criteria were selected using a simple random sampling technique, totaling 100 people.

\subsection{Variables}

The independent variables in this study are the knowledge and attitudes of respondents regarding cervical cancer. The dependent variable in this study is the attitude of respondents regarding cervical cancer and HPV vaccination participation. Data collection begins with managing permits and administering the place of activity, testing the validity and reliability of the instrument. Respondent data obtained through direct interviews using a prepared questionnaire.

\subsection{Data analysis}

The results of the questionnaire are presented in the form of categorical data then analyzed using Somers' correlation test with a significance level of 0.05 and a correlation coefficient (r).

\section{Results And Discussion}

Distribution of respondents according to knowledge and attitude showed on table 2, the majority $(65 \%)$ of female students were included in the category of sufficient knowledge about cervical cancer, but there were still $7 \%$ of female students with less knowledge. Based on the attitude about cervical cancer, the majority (72\%) of female students had a good attitude category, but there were still $8 \%$ female students with a lack of attitude. Of the 100 female students interviewed, it turned out 64 people $(64 \%)$ had received HPV vaccination, while 36 people (36\%) had not received HPV vaccination.

Table 1. Comparison of vaccination participation of high school female students and Vocational school students

\begin{tabular}{lcc}
\hline \multicolumn{1}{c}{ Characteristic } & Female Senior high School (n\% & Female Vocational High School (n\%) \\
\hline Ca Cervix Vaccination & $63(95 \%)$ & $1(3 \%)$ \\
Yes & $3(5 \%)$ & $33(97 \%)$ \\
No & & \\
\hline
\end{tabular}

Table 2. Characteristic of knowledge, attitude and HPV Vaccination 


\begin{tabular}{ccc}
\hline Variable & Frequency & Percent (\%) \\
\hline Knowledge & & \\
Good & 28 & 28 \\
\hline Moderate & 65 & 65 \\
Low & 7 & 7 \\
Attitude & & \\
Good & 72 & 72 \\
Moderate & 20 & 20 \\
Low & 8 & 8 \\
\hline
\end{tabular}

Table 3. The relationship between knowledge and respondents' attitudes about cervical cancer was analyzed using the Somers'd correlation test.

\begin{tabular}{|c|c|c|c|c|c|}
\hline \multirow{2}{*}{ Knowledge (n\%) } & \multicolumn{3}{|c|}{ Attitude (n\%) } & \multirow[b]{2}{*}{ p } & \multirow[b]{2}{*}{$\mathbf{r}$} \\
\hline & High & Moderate & Low & & \\
\hline High & $22(22)$ & $5(5)$ & $1(1)$ & 0.207 & 0.314 \\
\hline Moderate & $49(49)$ & $13(13)$ & $3(3)$ & & \\
\hline Low & $1(1)$ & $2(2)$ & $4(4)$ & & \\
\hline Total & $72(72)$ & $20(20)$ & $8(8)$ & & \\
\hline
\end{tabular}

The correlation test results show that there is a weak significant relationship between knowledge with attitudes of high school / vocational school students in Badung Regency regarding cervical cancer $(\mathrm{p}=0.036 ; \mathrm{r}=0.214)$

Table 4. The relationship between knowledge and respondents' attitudes about cervical cancer was analyzed using the Somers'd correlation test.

\begin{tabular}{lccccc}
\hline \multirow{2}{*}{ Knowledge of Ca cervix } & \multicolumn{2}{c}{ Ca Cerviks Vaccination } & \multirow{2}{*}{$\mathbf{~}$} & \multirow{2}{*}{ p } \\
\cline { 2 - 3 } & Yes & No & & \\
\hline Good & 48 & 24 & & \\
Enough & 15 & 5 & 0.134 & 0.207 \\
Poor & 1 & 7 & & \\
\hline
\end{tabular}

Correlation test results show that there was no significant relationship between attitudes of high school/vocational school students in Badung Regency regarding cervical cancer with participation in HPV vaccination $(\mathrm{p}=0.207)$.

Knowledge Relationship with Attitudes High School / Vocational School students in Badung Regency About Cervical Cancer

Based on the Somers'd correlation test, the results show that there is a weakly significant relationship between knowledge with attitudes of high school / vocational school students in Badung Regency regarding cervical cancer with. These results are in line with research that states that knowledge has a significant relationship with attitudes regarding cervical cancer. $[4,5,6,7]$ Although knowledge is said to be significantly related to attitude, the strength of a weak relationship is caused by many factors that influence the formation of a person's attitude. These results are supported by research on the factors that influence the attitudes of young women, in addition to good knowledge, personal experience is also a factor forming attitudes. Someone who has a personal experience of a stimulus tends to form a positive attitude towards the stimulus, and vice versa. [8.9] The experience of previous high school / vocational school vaccinations can influence their attitude towards cervical cancer. 
The factors forming attitudes include: the influence of people who are considered important, including parents, teachers, husbands, wives, or those with higher social status. Someone tends to have a unidirectional attitude to avoid conflict with that person. Culture is also related to the formation of attitudes. The culture in which we live has an influence on the concept of one's attitude. The mass media brings a lot of information that unwittingly gives suggestions to one's affective judgment. Religion and emotional factors also have an influence in forming attitudes. Religion puts the moral concept and the basis of understanding so that it can unconsciously provide an influence in taking attitudes. Emotion is the basis of an attitude statement, where emotions can affect a person's attitude that is temporary or permanent.10 Logical belief in an object will also form a positive attitude towards the object.[11] So, in forming attitudes regarding cervical cancer is not enough if you only see one variable (knowledge), there are still other factors that play a role in forming attitudes.

Relationship between High School / Vocational School Student Attitudes in Badung Regency Regarding Cancer Cervix with HPV Vaccination Participation

Based on the Somers'd correlation test, the results showed that there was no significant relationship between the attitudes of high school / vocational school students in Badung Regency and the participation of HPV vaccinations with $p=0.207(p>0.05)$. These results are in line with research that states that there is no significant relationship between attitudes and behavior.[4,12,13,14,15]

In this study, of 64 people who had received HPV vaccination, 48 people had good attitudes, 15 people had enough attitudes, and 1 person had a lack of attitude. Of the 36 people who have not received HPV vaccination, 24 people have a good attitude, 5 people have enough attitude, 7 people have a lack of attitude. These results illustrate that there is no tendency of respondents who have a good attitude to behave well because the respondents who are good but not yet vaccinated are quite high. Attitude is only a closed response to a stimulus. If a positive attitude is not followed up, it will not be a real response (behavior).[16]

In order for attitudes regarding cervical cancer to be manifested in the form of HPV vaccination behavior, there needs to be supporting factors, including facilities and ease of access, parental support, and a healthy physical condition.[4] Facilities and information about HPV vaccination are very important to facilitate access vaccination. In this study, $90.4 \%$ of vaccinated students received vaccinations through free programs in schools, especially in public high schools, while in vocational schools only $3 \%$ were vaccinated and not through free programs. It can be seen that, this program makes public high school students in Badung Regency more facilitated compared to private high school and vocational high school students and this free program is very influential on HPV vaccination participation. Parental support factors also play a major role in HPV vaccination decisions on unvaccinated students.[4] Parental support can be in the form of financing vaccinations and delivering them to health facilities. So, even though the respondent already has a good attitude towards cervical cancer and knows about HPV vaccination, if there is no support from parents, vaccination behavior is not realized. choose to delay vaccination. The attitude of high school / vocational high school students regarding good cervical cancer does not necessarily materialize with vaccination participation. There needs to be supporting factors so that vaccination participation becomes positive too.[17]

\section{Conclusions}


High school / vocational school students in Badung regency have a good attitude towards cervical cancer and almost have received HPV vaccination. There is a weak significant relationship between knowledge with attitudes of high school / vocational school students in Badung Regency regarding cervical cancer and no significant relationship found between attitudes of high school / vocational school students. It suggest to government that the free HPV vaccination program will be continued in schools and also expand the program implementation for private high school students and vocational school students in Badung Regency and for Puskesmas in Badung Regency routinely organizes health education activities on cervical cancer to high school / vocational school students to increase their knowledge and participation in HPV vaccination.

\section{References}

[1] ] Andrijino. 2009. Kanker serviks. 2 ed. Jakarta: Divisi Onkologi Departemen Obstetri Ginekologi FK UI; Vol 1:1-9.

[2] Departemen Kesehatan RI. 2015. InfoDATINkanker. Vol:4.

[3] Karneli NK. 2013. Kesediaan membayar vaksinasi kanker serviks di sekolah menengah umum Kabupaten Badung. Public Health and Preventive Medicine Archive. Vol 1(01):70-7.

[4] Dethan CM, Suariyani NLP. 2017. Pengetahuan dan sikap tentang perilaku vaksinasi HPV pada siswi SMA swasta. Jurnal MKMI. Vol;13(2):167-75.

[5] Rizki NA.2015. Pengaruh pendidikan kesehatan kanker serviks terhadap sikap pencegahan kanker serviks pada siswi kelas IX di SMP Negeri 2 Saptosari Gunungkidul Yogyakarta [naskah publikasi]. Yogyakarta: STIKES Aisyiyah Yogyakarta.

[6] Safrina L, Sari K, Mawarpury M. 2016. Hubungan pengetahuan, sikap, dan perilaku wanita dewasa muda terhadap kanker leher rahim. Jurnal Mediapsi. Vol 2(1): 19-28.

[7] Batas A, Mongan S, Mewengkang M. 2013. Pengetahuan dan sikap wanita mengenai kanker serviks dan pap smear di RSU Hermana Lembean Bulan November-Desember tahun 2013 [artikel skripsi]. Manado: Universitas Sam Ratulangi.

[8] Sariyati S. 2014. Faktor-faktor yang mempengaruhi sikap remaja putri tentang flour albus di SMP Negeri 2 Trucuk Kabupaten Klaten. Jurnal Ners dan Kebidanan Indonesia. Vol;117-21.

[9] Sulaini P, Novendra, Edison. 2014. Hubungan tingkat pengetahuan dengan sikap bidan mengenai teknik Inspeksi Visual Asetat (IVA) dalam skrining kanker serviks di Puskesmas Kota Padang. Obgyn Emas. Vol;1(15):23-8.

[10] Azwar S. 2013. Sikap manusia: teori dan pengukurannya. Yogyakarta: Pustaka Pelajar.

[11] Eagly AH, Chaiken S. 2010. The psychology of attitudes. Michigan: Hercourt Brace Jovanovich College Publishers.

[12] Chaleda SN, Kasanah U. 2016. Hubungan sikap dan persepsi terhadap kebutuhan dengan perilaku deteksi dini kanker serviks ibu bhayangkari di Poliklinik Bhayangkara Purwodadi [artikel skripsi]. Purwodadi: Akademi Kebidanan Bakti Utama Pati.

[13] Andriani T. 2014. Hubungan pengetahuan dan sikap terhadap penerimaan vaksinasi Human Papilloma Virus di kalangan ibu dari siswi SMP di Kabupaten Bantul dan Kota Yogyakarta [skripsi]. Yogyakarta: Universitas Gajah Mada.

[14] Hidayati ADN. 2017. Hubungan pengetahuan dan sikap ibu tentang kanker serviks dengan perilaku pemeriksaan IVA di Puskesmas Mlati I. [naskah publikasi]. Yogyakarta: STIKES Aisyiyah Yogyakarta.

[15] Parapat FT, Setyawan H. 2015. Faktor-faktor yang berhubungan dengan perilaku deteksi dini kanker leher rahim metode inspeksi visual asam asetat di Puskesmas Candiroto Kabupaten Temanggung 
[16] Notoatmodjo S. 2007. Pendidikan dan perilaku kesehatan. Jakarta: Rineka Cipta. Vol 1: 17180.

[17] Rachmani B, Shaluhiyah Z, Cahyo K. 2012 Sikap remaja perempuan terhadap pencegahan kanker serviks melalui vaksinasi HPV di Kota Semarang. Media Kesehatan Masyarakat Indonesia. Vol 11(1):34-41. 